\title{
Standard Deviation of Cell Density
}

National Cancer Institute

\section{Source}

National Cancer Institute. Standard Deviation of Cell Density. NCI Thesaurus. Code C120713.

A measure of the range of values in a set of values that describe the cell density. 